\title{
ChaPTer 11 Prosperity at A PRICE:
Regulation OF ORganized Labour in MALAYSia
}

\author{
JESSE WU MIN AUN
}

Since attaining independence in $1957,{ }^{1}$ Malaysia's relentless drive towards economic prosperity has been remarkable by any standard. A productive and inexpensive labour force is, among other things, an important contributing factor. In 1999, most reports suggest that the Malaysian economy is emerging from the financial and economic convulsion that had engulfed Asia. Malaysia adopted some home-grown remedies rather than seek assistance from the International Monetary Fund. The home-grown measures included the imposition on I September 1998 of the much criticized regime of capital controls to ward off currency speculators and the easing of interest rates to help over-leveraged companies.

The unorthodox medicine is showing results. Gross domestic product is expected to grow by more than 3 per cent in 1999, albeit from a low base after the economy contracted by 7.5 per cent in 1998 . The GDP growth rate may touch 5 per cent in the year 2000. Remarkably, the result has been achieved without the initial pains experienced by other stricken Asian countries. Indonesia, Thailand, and South Korea, were compelled to shut down companies and lay off workers as part of the mandated policies demanded by the International Monetary Fund which co-ordinated the multi-billion-dollar rescue packages (Toh, 1999).

Malaysia has largely used the breathing space provided by capital controls to effect some restructuring in the economy, particularly in the banking sector. A newly created asset management company, Danaharta, mopped up nonperforming loans in the system, while a recapitalization agency, Danamodal, injected funds into weak financial institutions. ${ }^{2}$

On the road to post-independence prosperity, the availability of reliable and inexpensive labour played a pivotal role in attracting foreign direct investment to selected industries although it came at a price. Now, labour appears even 'cheaper' following the 1998 financial crisis, which resulted in a dramatic plunge in the value of the ringgit. Once again, the country is attracting the attention of foreign investors eager to capitalize on any advantage. It is 
reported, for instance, that a US company, KOMAG Inc., is so eager to tap the cheap Malaysian work force that it is shutting two plants near its headquarters in San Jose, California, and re-locating all of its production to Malaysia. The maker of parts for computer disk drives says the move will slash payroll costs by 67 per cent, or US\$80 million (S\$134 million) a year. While Malaysia became something of a pariah in international financial markets because of slapping controls on capital flows in September 1998, it is now quietly luring more foreign investors like KOMAG to make their products in Penang and even in the town of Kuching, on the island of Borneo. ${ }^{3}$ The country's move to peg its currency, the ringgit, at 3.8 to the US dollar, appears to be the key motivation for the foreign investors; it has made Malaysia one of the cheapest places in the region to make almost anything. ${ }^{4}$ The cost of workers, land, and buildings has fallen, relative to its neighbours - effectively giving Malaysia a competitive advantage compared with countries such as Thailand and the Philippines, where currencies have strengthened.

Economic prosperity owes much to the availability of a cheap and compliant labour force secured mostly by severe regulation of industrial activities often justified on the grounds of either national integration or economic imperative. Laws governing industrial behaviour are largely restrictive and keenly enforced, with the government and the bureaucracy often quick to intervene in the face of a perceived threat to economic prosperity.

Central to this paper is an account of the regulatory framework of organized labour and the exercise of discretionary power by authorities to ensure that capital is well supported, by the availability of reliable and generally inexpensive labour for developmental goals. Particular attention is given to the legal regulation of trade unions and their ability to take industrial action in protection of their interest, highlighting, where relevant, the unusually wide discretionary power of the executive and public servants with respect to these matters. Particular attention is given to the two principal instruments of legal regulation, namely the Trade Unions Act 1959 and the Industrial Relations Act 1967.

\section{BACKGROUND}

The initial character of trade unions and their activities were largely moulded by considerations of security, politics, and race relations during the colonial and early post-colonial periods. The following significant events dictated the direction of the trade union movement and industrial relations:

1. Violent communist upheaval that erupted in colonial Malaya (as it was then called) in 1948. It led to a declaration of emergency by the colonial authority, 
the imposition of restrictions on civil liberties, a ban on the Malayan Communist Party and its activities and the enactment of laws providing for detention without trial. These and related events impacted heavily on the labour movement which was then closely associated with communism. The law relating to detention without trial has remained in the statute book in an extended version ever since and on one occasion, was utilized in an industrial strike. $^{5}$

2. Ethnic tension, in particular the racial riots of 1969 , caused a change in socio-economic strategy. On the political front, the federal government imposed restrictions on various freedoms, including the ability of workers to freely organize. Racial polarization is exacerbated by religious differences, where race is often identified with religion, and in employment. To be classed a Malay, one must also be a Muslim. In relation to employment, the public sector (public service, defence forces, and police) is dominated by Malays largely through a race-based preferential system. Chinese predominate in private enterprises and small businesses. Despite the ostensible appearance of ethnic harmony, tensions do surface from time to time. The New Economic Policy introduced in the aftermath of the racial riots of May 1969 was in part intended to redress the identification of race with economic activities, in particular to promote greater Malay ownership and participation in the private sector. Unfortunately, the preferential policies and their implementation have also fuelled resentment among non-Malays who perceive an injustice, given that they continue to be shut out of the public sector and public tertiary education while inroads are made into their traditional areas of activities. ${ }^{6}$

3. Laws prohibiting trade unions from participating in or financing political parties and their activities and vice versa isolating organized labour from the political arena.

In the immediate post-war period, organized labour in the form of the General Labour Union (hereafter referred GLU), was heavily infiltrated by communists. It opened its head office in Singapore soon after the Japanese ended their occupation of Malaya and Singapore in 1945. The GLU quickly assumed a preeminent role in the labour movement through rapid expansion into all major towns in Malaya to the north of Singapore. The immediate postwar period was plagued by chronic inflation and acute food shortages - ideal breeding conditions for labour disputes. The grievances were genuine enough. The newly liberated territories were engulfed in a state of socio-political sickness stemming from a lack of economic planning, absence of democratic labour institutions and the mistrust of communalism in a multiracial society. The GLU skilfully exploited the situation by taking on the pre-eminent role of leader and 
organizer of workers. A state of intensified general unrest soon ensued. The colonial administrators, through either general indifference or ineptitude, had unwittingly caused workers to fall victims to the political ambition of the GLU. Strikes and demonstrations intensified and coupled with popular demands for more rice, freer movement of food, exemption from water and electricity bills, higher prices for tin and rubber, etc., the territories slowly descended into chaos and industrial strife.

Trade union laws in Malaya lagged well behind those of the United Kingdom. No trade union legislation existed in Malaya until 1940. The colonial view was that unlike home, there was no need for such laws in the territories. After all, employed labour was largely comprised of immigrants and any labour unrest could be quickly dealt with by a combination of police action, arrests, and banishment, if a migrant participated. The local police could always be relied upon to break strikes. The colonial authority, influenced mostly by local British interests, did not see the need for trade union law in that environment. If anything, organized labour was regarded as a pain and promptly discouraged. What was desirable in the mother country was not necessarily regarded as appropriate in colonial possessions.

The first trade union law enacted in 1940 was motivated largely by financial considerations. The United Kingdom Parliament had earlier passed the Colonial Development and Welfare Act 1940, which contemplated various schemes for long term financial assistance by the mother country to the colonies, on the condition, that there were laws protecting trade unions, fair wages, children in employment, and related matters. The lure of money seems to have stirred the minds of an otherwise lethargic colonial authority in Malaya.

The Trade Union Enactment 1940, originally enacted for the Federated Malay States, was not at the time implemented as the Japanese invaded the territories soon after. Upon British reoccupation, the law was extended in 1946 to cover the whole of the Malay Peninsula which had been reconstituted ${ }^{7}$ into a new political entity called 'Malayan Union.' It consisted of 9 Malay States and the colonies of Penang and Malacca. Singapore was excluded from the shortlived Union.

The law introduced a scheme of compulsory registration for all trade unions. A Department of the Registrar of Trade Unions was created for the purpose of registering and supervising trade unions and their activities. A Trade Union Adviser's Department was added, whose purported duties were to foster the growth of trade unions, to assist them in negotiations with employers and to advise them on how best to build up their membership, finance, and leadership. In respect of employers' organizations, the Adviser's responsibility was limited to providing assistance upon request in respect of negotiating procedures and settlement of disputes. 
Compulsory registration of trade unions under the law began in earnest in 1947. By the end of the year, the figures revealed the existence of 289 unions with a total membership of 195,113 . It was estimated that nearly half the membership was under communist control exercised through the successor of GLU, the Pan-Malayan Federation of Trade Unions ('PMFTU') (ILO Report, 1962:30). Communist and trade union activities in the private sector were largely associated with the Chinese community with a smattering of Malays and Indians ${ }^{8}$ but in the public sector communist influence was relatively insignificant.

The year 1948 marks the turning point in the Malayan trade union movement. Heightened frequency and momentum of strikes, many of which had political overtones, caused the colonial government to react with repressive measures, presumably in the conviction that British colonial interests were under threat. Control over trade unions and their activities was tightened through amendments to the Trade Union Enactment in June 1948. Registration of federations of trade unions became compulsory and their membership restricted to trade unions whose members were employed in similar trades, occupations, or industries. ${ }^{9}$ The restriction of membership to similar trades, occupations or industries spelt an end to federations of a general nature - in practical effect, an end to large federations of trade unions. Henceforth, they would be broken up into smaller units. Another amendment made it compulsory for trade union officials, other than the secretary, to have at least three years' experience in the industry of their unions. The intent being to remove outside influences and 'infiltration,' thus ensuring that only genuine workers would hold office.

The PMFTU reapplied for registration as required by the new law. Along with about a hundred other unions, their applications were predictably rejected given the requirement that a federation must also be comprised of trade unions whose members were employed in similar trades, occupations or industries. The rug was swept out from under their feet. The new law ended their agenda of using trade unions as a front for securing political power.

The Malayan Communist Party, finding its activities through trade unions drastically curtailed, altered strategy and embarked upon a violent campaign of guerilla warfare. That strategy changed the course of Malaysian contemporary history, which had, until then, been relatively free of violent political activities. Prior to taking to the jungle, the Malayan Communist Party quietly spirited away whatever trade union funds it could lay its hands on. In response to the growing violence, the government banned the Malayan Communist Party and declared a state of emergency on 16 June 1948. The impact of the events on trade unionism may be summarized from the Report of the International Labour Office on the trade union movement: 


\section{JESSE Wu MIN AUN}

... their sudden disappearance left thousands of the rank and file leaderless, bewildered and disillusioned. Realising that many of their sacrifices had been in vain and that they had been made the plaything of political parties, a large percentage of the workers began to lose faith in trade unionism and all it stood for. As the Emergency dragged on, this attitude became more widespread and it was a long time before the effects of the 'let down' began to wear off (ILO Report (1962).

Although Malaya attained Independence in 1957, the state of emergency declared by the colonial authority remained in place. It did not formally end till 1960 but self-rule effectively ended the main communist platform of anticolonialism. Despite the formal ending of the state of emergency in 1960, pockets of insurgency continued for a while, particularly in the regions bordering Thailand. It was only in 1993 that the communists formally abandoned their struggle and signed an agreement in return for certain amnesty.

Given that background, it is not surprising that successive postindependence governments were suspicious of trade unions. They adopted a fiercely anti-communist policy. While recognizing the need for trade unions, they took the view that labour policies should not be liberal, given that until the end of the Cold War, the nation had remained under the threat of communism, and in light of their past experience with communists.

Apart from the communist factor, two other major events in the 1960s impacted heavily on the nation and came to dominate its life. The first event was the merger in 1963 of the States of Sabah, Sarawak, and Singapore with the Federation of Malaya into an enlarged federation, renamed 'Malaysia.' It triggered Indonesia into hostility in an undeclared war (called 'Konfrontasi'), publicly proclaiming the new federation as neo-colonialism. That undeclared war went on from 1964 to 1967 . The second event was the 1969 race riots when race relations were shattered. Both events caused successive emergencies to be declared. The 1969 emergency has remained in force since, despite the cessation of the circumstances of its declaration. New laws that were introduced during this period diluted various freedoms, including that of organized labour.

With respect to industrial relations, these events mapped out its future direction. The already strict legislative controls over trade unions were further tightened in several areas. The government hardened in its view that trade unions must continue to be isolated from political activities, their main function limited to the protection of workers for economic advancement. In political speak, it intends to ensure a compliant labour environment for developmental goals. 
The restrictive nature of industrial relations law in contemporary Malaysia owes much to this backdrop. Since independence, Malaysia has taken a relentless path towards the twin objects of nationalism and economic prosperity, and in respect of the latter, the attainment of a fully industrialized status by the year $2020,{ }^{10}$ despite the setback of the $1997 / 1998$ recession.

\section{REgulation OF TRADE UNIONS}

Trade unions affairs and industrial conflicts are tightly regulated. The government exercises wide administrative discretion, to support legislative controls, in its efforts to secure industrial harmony. The regulation of trade unions and industrial activities is relatively simple because federal law and not a plethora of state laws govern trade unions and industrial relations. Two pieces of federal legislation, viz the Trade Unions Act 1959 (hereinafter referred to as TUA) and, to some extent, the Industrial Relations Act 1967 (hereinafter referred to as the IRA), cover the whole area.

The TUA was first enacted as FMOrdinance No. 23 of 1959 and revised on 21 November 1981 as Laws of Malaysia Act 262. Since its revision, substantial amendments have been made to the Act from time to time. ${ }^{11}$

\section{REGISTRATION OF TRADE UNIONS}

The right of both employers and employees to form trade unions and to engage in their legitimate activities are embodied in the IRA. In particular, s 4(1) of the IRA declares:

No person shall interfere with, restrain or coerce a workman or an employer in the exercise of his rights to form and assist in the formation of and join a trade union and to participate in its lawful activities.

The right exists in respect of registered trade unions. Unregistered trade unions are treated as illegal organizations so that persons involved in their activities become liable to criminal sanctions.

Strict statutory guidelines govern the process of registration. An application for registration must be made to the Director General within one month from the date of the establishment of a trade union although this period may be extended at the Director General's discretion, but such an extension must not exceed six months in the aggregate (TUA s 8). A trade union is deemed to have been established on the first date on which any employees or employers agree to become or create a trade union (TUA s 9(1). This necessarily assumes that 
the body is established in furtherance of any one or more objects specified in the definition of a trade union contained in s 2(1).

For the purpose of prosecution for non-registration, unless proven otherwise, the date of establishment is presumed to be:

(a) the date on which any person is proved to have been accepted or admitted as a member of that trade union; or

(b) the date on which any act is proved to have been done by that trade union in furtherance of any one or more objects of a trade union; and

(c) in a case where proof is available of both dates referred to in items (a) and (b) above, the earlier of such dates TUA s $9(2)$.

Upon registration, a trade union is entitled to certain rights, immunities, and privileges, for example, it could bargain for and withdraw labour without the threat of such common law action as breach of contract of employment or other tortious actions.

To be eligible for registration, trade unions must be organizations (permanent or temporary) that consist wholly of either employees or employers of one establishment or of one or more descriptions. Unions of a general nature are not registrable under the Act except perhaps within a particular establishment. Any association of employees or employers that is caught by the statutory definition is regarded as a trade union even though it may not have been registered under the law as such.

Membership of a trade union is restricted to workers or employers, as the case may be, "within any particular establishment, trade, occupation or industry or within any similar trades, occupations or industry. ${ }^{, 12}$ A prospective union is not registrable if its membership includes unrelated establishments, trades, occupations, or industries. In other words, unions of a general nature are not registrable except in a particular establishment.

The same rule applies in respect of federations of trade unions where membership consists of constituents or affiliations of trade unions. Each federation must consist only of trade unions whose members are employed in a similar trade, occupation, or industry. ${ }^{13}$

The restriction was first enacted, by the colonial authority, in 1948 in respect of federations of trade unions as part of a wider strategy to break up and control the labour movement. The same was later extended to trade unions in 1959. The application of this provision has both a positive and a negative impact on the trade union movement: Positive in that membership of particular trade unions is largely homogeneous but negative in that trade unions are generally fragmented, small and resources rather limited. Emerging also is an increasing number of in-house unions. Their strength as bargaining units is 
relatively weak by comparison with trade unions in industrialized nations and the weakness seems to serve the purpose of government public policies.

\section{Regulation through Administrative Discretion}

The exercise of administrative discretion in public affairs is a familiar theme in Malaysian administrative law. Its application in relation to trade unions and industrial relations fits snugly into this pattern. As mentioned earlier, to qualify for registration (whether of workers or employers, as the case may be) a trade union must be 'within any particular establishment, trade, occupation, or industry or within any similar trades, occupations or industry.' The decision as to whether a trade, occupation, or industry is 'similar' is vested in the Director General of Trade Unions. According to the TUA s 2(2), for the purposes of the definition (and several other purposes) the word 'similar' means 'similar in the opinion of the Director General. ${ }^{14}$ Although any person dissatisfied with the opinion of the Director General on the issue of similarity may appeal to the Minister within thirty days from the date of the opinion, the exercise of power in the negative amounts to a veto by a public servant. On appeal, the decision of the Minister is 'final and conclusive' (TUA s 71A).

The Act is silent on the question of judicial appeal or review in relation to an opinion of the Director General or the Minister on the similarity or otherwise of a trade, occupation or industry. It would appear that the intention is to shut out the courts. Under current practice, courts will not normally intervene before statutory procedures are exhausted, and even when they do intervene, it is on rather limited grounds. This judicial approach in respect of the former is well illustrated in the case, Metal Industries Employee Union $v$ Registrar of Trade Unions [1976] 1 MLJ 80, where the Registrar expressed an opinion under s 2(2) of the 1959 Ordinance. That opinion was challenged in the High Court by way of an application for a declaration. Though the High Court agreed that there was a question of interpretation, it declined to intervene on a procedural ground; that there was an alternative statutory remedy by way of an appeal to the Minister.

How the Director General applies his or her mind to the test of 'similar trade, occupation, or industry' is far from clear. One can only hazard a guess, that the process for its determination involves interpretation of facts. 'Similar' is a question of degree. It is a subjective determination, and ordinarily, it is made by reference to the trade, occupation, or industry and the membership rules of the union concerned. In Tanjong Jaga Sdn Bhd v Minister of Labour \& Manpower [1987] 1 MLJ 124, the argument was put that it was incumbent on the Registrar (as the officer was previously referred to) to make due inquiry by considering evidence from both sides. Abdoolcader SCJ, rejecting that suggestion, said: 
There is no provision or requirement for due inquiry as such and all that was necessary was a fair and reasonable decision arrived at by the Registrar in the exercise of his discretion. ... In exercising his functions in this regard, the Registrar had an unfettered discretion which was subject to a duty to act responsibly (p. 129).

His Lordship, however, conceded that a decision could be challengeable but only if the '.. decision making body comes to its decision on no evidence or comes to an unreasonable finding so unreasonable that a reasonable person would not have come to it - then the court will interfere' (In Tanjong Jaga Sdn Bhd V Minister of Labour \& Manpower [1987] 1 MLJ 124 p. 129).

In the electronics industry, the Director General seemed to take a narrow view and ruled that employees could not be represented by a union of electrical workers. In his view, the electronics industry is not similar to the electrical industry. Lee Hun Hoe CJ in Electrical Industry Workers Union $v$ Registrar of Trade Unions [1976] 1 MLJ 177 p. 179 said:

Whether a person in a related or similar industry becomes a member of a particular union is squarely a matter for the decision of the Registrar of Trade Unions. If a particular union could say it is for the union to decide whether those in another industry might be absorbed as members of the Union, a dangerous situation would develop whereby each and every union in the country would do the same ... It is for the Union to satisfy the Registrar of Trade Unions that the Monsato Electronics Workers Union belongs to the same or similar industry as the Union (Electrical Industry Employees Union).

The electronic industry has traditionally been dominated by direct foreign investments. Close control of trade union activities certainly gives encouragement to foreign investors given that the workforce will be largely docile and free of industrial strife. Investments in such industries fit neatly into official perception of national interests.

\section{Restriction of Trade Union Activities}

The TUA limits the range of trade union activities, for example, political activities are banned. Restriction is achieved by listing a number of objectives and requiring a trade union to have, among its objectives, one or more of them and nothing else. These objectives are enumerated in s 2(1)(c) as follows:

1. The regulation of relations between employees and employers for the purposes of promoting good industrial relations between them, improving 
the working conditions of employees or enhancing their economic and social status, or increasing productivity;

2. The regulation of relations between employees and employees, or between employers and employers;

3. The representation of either employees or employers in trade disputes;

4. The conducting of or dealing with trade disputes and matters related thereto;

5. The promotion or organization or financing of strikes or lock-outs in any trade or industry or the provision of pay or other benefits for its members during a strike or a lock-out (TUA s 2(1)).

It may be noted that none of the above objectives relate to political or related activities. By way of comparison, in some European countries such as Sweden, the relationship between political parties and trade unions are so close that the latter would have political wings. Malaysia has deliberately isolated trade unions from political parties and their activities. In practical terms, political aspirations are prohibited in the trade union movement. In addition, TUA s 52(1) expressly provides that trade union funds 'shall not be applied directly or indirectly in any payment whatsoever to a political party or in furtherance of any political object.' That rules out political donation.

The expression, 'political object,' is comprehensively defined in s 52(2), ${ }^{15}$ culminating in a 'catch all' clause - 'any object which the Minister may by notification in the Gazette specify.' The Act is silent on criteria, norms, or standards that may provide a guide to the Minister in the exercise of his discretionary power in this area. It is a classic case of unfettered executive power.

Such unfettered executive power may seem extraordinary to the uninitiated. In Malaysia, it is unremarkable given its regular use. The Malaysian statute book is littered with clauses conferring discretionary power to be exercised by the executive or his/her delegate. One is inclined to question why the legislature has provided such wide powers on the executive. The answer behind s 52 is easily traceable to the emergence of strong executive government. Moreover, in the past, trade unions outside the public sector have more often than not supported opposition parties rather than the ruling coalition for a variety of reasons, which it is not necessary to speculate upon for the purpose of this chapter. Given that the same coalition party in different permutations has governed since independence in 1957, the motivation for insisting that trade union activities be totally separated from political activities becomes obvious. It should also be recalled that in the early development of the labour movement in peninsular Malaysia, trade unions were heavily infiltrated by communists. Despite the ending of the Cold War, the government remains anticommunist. Consciously or otherwise, it is much influenced by the old spectre 
of communist dominated organized labour. Until 1955, trade unions were allowed to use funds for political purposes. So why should this right 'be abolished in 1980, when the Government is freed of Communist threats. ${ }^{.16}$ The answer lies not in the strength of the question but in the fact that a government long used to exercising power is not likely to surrender it or see it wrestled away by its opponents.

It may also be noted that $\mathrm{s} 28(1)$ of the TUA prohibits an officer-bearer or employee of a political party from holding office in a trade union, including a branch and a federation of trade union. Where the Director General certifies in writing to the executive of a trade union, or a federation of trade unions, that a member of the executive is disqualified from holding office, the person immediately ceases to be a member of such executive. There appears to be no provision in the Act for appeal against the decision of the Director General.

Persons may be exempted from the operation of the above disqualification but such exemption is granted by the Minister through an order exempting either the trade union or officers of a trade union (TUA s 30 ).

Disqualification of office bearers and employees of political parties from holding offices in trade unions had its origins in the 1969 Essential (Trade Unions) Regulations, a law made under emergency powers in the wake of racial riots. These provisions have since become entrenched. They are now sections 28 and 29 of the Act. Prior provisions for separate political funds in trade unions were repealed. In the result, it is now unlawful for any union to use any of its funds for political objectives (TUA s 52). The overall impact of the change means that political parties and trade unions have become almost completely separated ${ }^{17}$ with no formal links between them.

\section{Public Sector Union}

Trade unions in the public sector are also separated from those in the private sector. Employees of statutory authorities are prohibited from joining or becoming members of any trade union 'unless the membership of that union is confined exclusively to persons employed by that particular statutory authority' (TUA s 3(a)). This restriction means that employees of a statutory authority cannot join private sector unions even if they belong to the same trade or occupation. In addition, they are restricted to a union of 'that particular statutory authority' (Essential (Trade Unions) Regulations 1969). It would seem that 'in-house' unions are the only type of organized labour allowed in statutory bodies (A732 Trade Union (Amendment) Act 1989).

As an exception, an employee of a statutory authority may join an outside union provided that the trade union's 'membership is confined exclusively to employees of one or more financially autonomous local authorities' and only with approval of the Minister of Human Resources. It is intended as a concession to statutory authorities too small to form separate bodies. There 
appears to be no guideline provided to the Minister in considering an application for such approval. Presumably, the Ministerial authority is completely discretionary in nature.

Given the various legal constraints, it is not surprising that statutory authority employees unions are generally small in membership.

The general rule as stated in $\mathbf{2} 27$ of the TUA prohibits public officers from joining or becoming members of any trade union unless exempted by the Yang di-Pertuan Agong (the King). The Yang di-Pertuan Agong may allow an exemption by notification in the Gazette but subject to such conditions as may be specified. Such exemption was given by the Trade Unions (Exemption of Public Officers) Order 1971 which permits public officers to organize on the condition that union membership is confined to public officers within a particular occupation, department or ministry.

\section{Ministerial Power to Suspend a Trade Union}

The Minister of Human Resources possesses the power, exercisable at his 'absolute discretion,' to suspend for a period not exceeding six months any trade union, or any class or description of trade unions, which 'in his opinion' is or is being used for purposes prejudicial to or incompatible with the interests of the security or public order of Malaysia or any part thereof (TUA s 18). The discretionary power is exercisable subject to certain constraints, namely:

a. the concurrence of the Minister responsible for internal security and public order; and

b. the publication of the suspension order in the Gazette.

The need to publish is merely procedural and a condition precedent to its enforcement. Its real value is illusory, given that the procedure may be dispensed with 'where in the opinion of the Minister the exigencies of the situation so require.' Hence the Minister may suspend a trade union immediately upon an order being made and before its publication but 'after publicising it in such manner as the Minister thinks fit,' for example, by a press statement or an announcement in the mass media. It is indeed an extraordinary discretionary power.

It is also provided in the Act that the Minister's order is 'final and conclusive' (TUA s 18(7)). In practical terms, it is not normally amenable to judicial review except perhaps for the most blatant error of law. It has been argued that the power is needed to meet grave situations that are likely to threaten security or public order. It is an unconvincing argument. In reality, it is yet another illustration of an authoritarian approach to government taken through force of habit. Such power is superfluous given the extraordinary powers that already exist under Articles 149 and 150 of the Federal 
Constitution, and the laws made thereunder, to deal with activities that have the potential to threaten security or public order. ${ }^{18}$

The Minister's authority to suspend is not restricted to a particular trade union. It is exercisable in respect of any class or description of trade unions. It is conceivable that a Minister, for instance, may decide to suspend all trade unions in the whole industry, if he/she is of the view that they are being used for purposes prejudicial to the interests of public order. Such suspension may occur despite the legitimacy of trade union claims and the fact that they have followed all procedural requirements prior to industrial action. The power of government over trade unions seems almost limitless.

Upon the making of an order of suspension, the Minister has authority at any time to give further directions of an ancillary or consequential nature as he may deem necessary or expedient. A direction so given is valid, notwithstanding anything inconsistent with the TUA and it is also 'final and conclusive.' Again, no guideline or criterion is prescribed for the exercise of this power. The most significant aspect of a ministerial direction is the fact that it is 'valid and have full force and effect' even though it may be contrary to the statute from which the power originates (TUA s $18(4)(b)$ ). In a democratic society, it must surely rank as one of the most undemocratic of powers. It would seem that the legislature has abdicated its responsibility.

The current state of the law is a demonstration of blatant executive power over trade unions and their activities.

The tendency of the legislature, under executive direction, to confer wide discretionary powers to administrative authority to decide matters according to its subjective satisfaction is now legendary. From the foregoing discussions, this approach is amply illustrated. The discretionary nature of the power is demonstrated by the use of such terms as 'he is of the opinion,' 'if he is satisfied,' and 'in his absolute discretion.' All the above expressions are found in the TUA. While it is administratively efficient, it also erodes democratic principles and creates a climate conducive for abuse of power, particularly where the traditional authority of courts to review is ousted at the same time. Clearly when an administrative authority is vested with discretionary powers to be exercised according to its subjective satisfaction, the courts are loath to inquire into the merits. Generally it is regarded as a non-justiciable matter. ${ }^{19}$

\section{REgULATION OF STRIKES}

A strike is perhaps the most dramatic manifestation of overt industrial conflict. In a civil society, the freedom of workers to combine and to withdraw their labour is widely recognized as a legitimate form of industrial action. It is seen 
as the ultimate safeguard against the inherent imbalance of power between capital and labour.

A strike involves a concerted temporary withdrawal of labour by a group of workers for the purpose of protecting or promoting their interests. Workers' interests normally relate to the terms and conditions of employment of the strikers or in an industry but in countries with a liberal democracy such as Australia and the United Kingdom, other interests that may be sought to be protected or promoted through strikes and other industrial actions do not necessarily relate to employment matters alone but may involve other issues such as political or environmental concerns. Modern trade unions often take on wider agendas, including politics, but in the case of Malaysia, that is not the practice given that the law prohibits workers from engaging in strikes unrelated to their employment. In consequence, their concerns are far narrower and limited.

\section{Control of Strikes}

Embarking on strike action in Malaysia is similar to running the marathon. It is long, hard, and a test of endurance.

Strike is strictly controlled by legislation through various techniques. In the first instance, the word 'strike' is given an expansive statutory meaning; thus snaring a multitude of actions that might be employed by trade unions in furtherance of industrial conflicts, within the ambit of strike laws. Section 2 of the IRA and s 2(1) TUA define a 'strike' in similar terms to mean:

The cessation of work by a body of workmen acting in combination, or a concerted refusal or a refusal under a common understanding of a number of workmen to continue to work or to accept employment, and includes any act or omission by a body or workmen acting in combination or under a common understanding, which is intended to or does result in any limitation, restriction, reduction or cessation of or dilatoriness in the performance or execution of the whole or any part of the duties connected with their employment.

Three elements are present in the above definition: (a) cessation of work; (b) action less than cessation of work but which results in a limitation, restriction, reduction, or dilatoriness in the performance of work and (c) concerted action. Thus industrial acts such as 'go slow,' 'work to rule,' overtime ban, and so forth, which do not involve a complete cessation of work, are caught by s 2 . They are regarded as strikes and therefore subject to various controls. Trade unions cannot resort to 'go slow' or 'work to rule' and claim that they are not on strike. Given this wide definition of what constitutes a strike, not surprisingly strike action in general is not particularly widespread. 


\section{Is there a Right to Strike?}

There is no statutory provision expressly conferring on workers the right to strike. The right to strike is inferred from several provisions of both the TUA and IRA. The relevant provisions are as follows:

1. TUA s 2(1) provides amongst the objects of a trade union "the promotion or organisation or financing of strikes or lock-outs in any trade or industry or the provision of pay or other benefits for its members during a strike or lock-out;'

2. TUA s 21 provides a registered trade union with legal immunity from civil suit in respect of any act done in contemplation or furtherance of a trade dispute. Trade disputes include strike action;

3. TUA s 25A provides for a mandatory procedure, including the taking of a secret ballot, before strike action can commence;

4. IRA s 4(1) provides that "No person shall interfere with, restrain or coerce a workman or an employer in the exercise of his rights to form and assist in the formation of and join a trade union and to participate in its lawful activities.' The lawful activities of a trade union include the promotion, organisation and financing of a strike as indicated in item (1) above;

5. IRA s 42(1) and (2) prevents persons acting in combination in contemplation or furtherance of trade unions from being prosecuted or sued for their actions;

6. The Employment Act $1955 \mathrm{~s} 8$ provides that nothing in any contract of service must restrict the right of any employee from participating in the activities of a registered trade union. Such activities would presumably include strikes.

The right of workers to strike is supported by judicial pronouncements. For instance, Raja Azlan Shah FJ in South East Asia Fire Bricks [1976] 2 MLJ 67 p. 19, citing with approval a statement of Lord Wright, which says:

It is declaratory of present day industrial relations that management should encourage workmen to join a union and to play an active part in its work, ... such as the freedom to strike. "The right of workmen to strike is an essential element in the principle of collective bargaining' per Lord Wright in Crofter Hand Woven Harris Tweed Company, Ltd and Ors $v$ Veitch \& Anor. That is a truism. There can be no equilibrium in industrial relations today without the freedom to strike. If workers could not, in the last resort, collectively withhold labour, they could not bargain collectively. 
His Lordship elaborated, 'the freedom to strike appears in the form of immunities from criminal prosecution and from civil action,' provided the actions are taken in contemplation or furtherance of trade disputes. The same case is also authority for the proposition that workers who go on lawful strike have not terminated their contracts of service but are merely suspending it for the duration of the strike. Consequently, an employer cannot, by issuing warning notices, convert the absence from work of those workers, who are on strike, into abandonment of their service contract.

\section{Mandatory Requirements for Lawful Strikes}

While the right to strike seems settled, the road towards it is long and arduous. Firstly, only registered trade unions may go on lawful strike, and second, the strike must be in contemplation or furtherance of a trade dispute between the workers on strike and their employer. A strike in support of other workers is illegal, given that a trade dispute must involve a dispute with their employers. Thirdly, strikes for political, economic, social, or related purposes such as environmental concerns are illegal and persons so participating are liable to prosecution.

Sections $25 \mathrm{~A}$ and 40 of the TUA impose certain compulsory procedures to be observed before a trade union can commence a lawful strike (or a lock-out in the case of an employer). Failure to observe the prescribed procedures can lead to prosecution and, in the event of a prosecution for infringement, the burden of proof is reversed. ${ }^{20}$

In a criminal case, the prosecution is normally required to prove the guilt of the defendant beyond reasonable doubt. It is quite puzzling that in relation to a breach of the law relating to strike, the burden of proof is reversed. Surely industrial disputes are not a greater threat to the community as a whole than criminal activities. Shifting the burden of proof to a defendant places a heavy burden of responsibility on trade unions, their officers and members. The government conveys the impression that it is less tolerant of unlawful industrial action than of other criminal activities. Given the already tight regulation of strikes, it is draconian to treat industrial law violators more harshly than criminal offenders.

Among the several mandatory procedures of a lawful strike is the taking of a secret ballot in a decision on 'all matters relating to strikes and lock-outs' (TUA s 40(1)). It is a condition precedent to a lawful strike (or lock-out). Secret ballot is an issue of union democracy and reduces incidence of intimidation. By and large, it is generally agreed that it is an appropriate procedure: for a decision to strike being tested democratically on the floor through a secret ballot. Other methods of determining support such as a show of hands and associated methods at open forums are not satisfactory. 
However, before a secret ballot can be taken in relation to any matter concerning a strike or lock-out, a proper resolution must be circulated setting out clearly the issues leading to the proposed strike or lock-out and a description of the nature of the industrial action, which is contemplated, in the course of such a strike or lockout. A secret ballot not conducted correctly is invalid and of no effect, and 'no strike or lock-out shall be carried out on the basis of such secret ballot.' It is clear that industrial actions such as wildcat strikes, where members walk out off their jobs without notice, are illegal.

A strike decided by secret ballot must be supported by at least two-thirds of the total number of union members, who are entitled to vote, and in respect of whom the strike is to be called. The same is required of employers in the case of a lock-out (TUA s 25(1)(a)). A simple majority of members in support of a strike is insufficient.

\section{Role of the Director-General in Strikes}

The Director General of Trade Unions plays a major role in matters relating to strike action. Pursuant to s 40(5) of the Act, the results of a secret ballot on a strike or lock-out must be submitted in triplicate by the secretary of the trade union to the Director General within fourteen days of the taking of the ballot. The secretary is under a legal duty to take all steps to ensure that all ballot papers and documents used in connection with the secret ballot are kept at the registered office of the union for a period of not less than six months after the completion of the ballot (TUA s 40(7)).

Upon receipt of the results of a secret ballot calling for a strike or a lockout, the Director General is empowered by s 40(6) of the Act to 'carry out all such investigations as he may deem necessary.' For the purpose of satisfying himself that a secret ballot taken by a trade union has been properly conducted according to law and the rules of the union concerned, he may act in the following manner:

1. require any person to deliver to him any ballot papers, envelopes, lists, or other documents, which have been used in connection with the secret ballot;

2. inspect any such documents; and

3. retain them for such period as he deems necessary.

Other than the Director General, as provided in the rules of the union, no other person 'shall be allowed to inspect or copy any document relating to a secret ballot.' 
The Director General may decide as follows:

1. take note of the secret ballot calling for strike or lock-out;

2. declare the secret ballot taken to be invalid if he is satisfied that the union has contravened any provision of the Act or its regulations, or any of its own rules in carrying out such secret ballot (TUA s 40(9)); or

3. direct the union not to commence any strike or lock-out where he is satisfied that the proposed action if carried out would contravene the Act or any other written law (TUA s 40(6)).

The power of the Director General under item (3) above is exercisable at his subjective discretion. It is unclear whether the Director General can direct that a proposed strike be aborted because in his subjective view, the proposed strike would contravene the Act or 'any other written law,' regardless of a secret ballot in favour of a strike or lock-out, with no ostensible flaw in its conduct. If the answer is affirmative, the Director General's power is indeed far reaching. Is the Director General an appropriate person to decide subjectively whether an industrial action has contravened or is likely to contravene a written law? Surely that is a function of the court rather than a public servant. The provision as it stands gives far too much authority to a public servant.

\section{Cooling Off Period}

A 'cooling off' period is also prescribed by law. Following the submission of the results of a secret ballot in favour of a strike to the Director General, at least seven days must elapse before a strike or lock-out can actually commence (TUA s $25 \mathrm{~A}(1)(\mathrm{b})$ ). A strike or lock-out carried out or declared in contravention of s $25 \mathrm{~A}(1)$ is illegal. Any trade union and every member of its executive who commences, promotes, organizes, or finances such illegal strike or lock-out is liable, on conviction, to a fine not exceeding two thousand ringgit, or to imprisonment for a term not exceeding one year, or to both. There is a further fine of one hundred ringgit for every day the offence continues (TUA s 25A(2)). This prescribed 'cooling off' period is probably intended to provide some breathing space for both protagonists to reach a settlement.

\section{Restriction of Strikes in Certain Circumstances}

In certain circumstances, strikes are completely prohibited, namely:

1. Recognition of trade unions: $\mathrm{s} 10(1)$ prohibits a worker from taking strike action for "whatever reason during the pending of proceedings under section 9, or after the decision of the Minister thereunder by reason of any dissatisfaction with such decision.' Section 9 concerns a claim by a union for recognition from an employer. It would appear that once a trade union 
has served a claim for recognition on an employer, a statutory process is put in train and during that period, workers are prohibited from going on strike. Employers are likewise prohibited from declaring a lock-out or from terminating the services of their employees;

2. Essential industries: $s 43$ places restrictions on strikes and lock-outs in 'essential industries.' A prescribed period of notice is required before a strike can commence;

3. Other miscellaneous circumstances: $s 44$ prohibits workers and employers from resorting to strikes and lock-outs respectively in any of the following circumstances:

(a) during the pendency of the proceedings of a Board of Inquiry appointed by the Minister in respect of a trade dispute involving such workers and employer, and seven days after the conclusion of such proceedings;

(b) after a trade dispute or a matter involving such worker or employer has been referred to the Industrial Court for settlement, and the parties concerned have been notified of such reference;

(c) in the case of a trade dispute relating to any public service or the service of a statutory authority, after the Yang di-Pertuan Agong has withheld consent to a reference of the dispute to the Industrial Court under $\mathrm{s}$ 26(2), and the parties concerned have been notified;

(d) in respect of any of the matters covered by a collective agreement that has been taken cognizance of by the Industrial Court in accordance with s 16 or by an award; and

(e) in respect of any of the matters pertaining to management's prerogatives that are not to be included in a union's proposal for a collective agreement covered by s 13(3).

Where a trade dispute relates to the public service or a statutory authority, workers may have no means of redress if the Yang di-Pertuan Agong or the relevant state authority refuses to give its consent for a dispute to be referred to the Industrial Court. In practical terms, these workers are denied the benefits of either compulsory arbitration or the right to strike in order to force a settlement of their grievances. In this respect, workers in the public sector are at a relative disadvantage in comparison with their counterparts in the private sector. By virtue of s 45(1), strikes and lock-outs are deemed to be illegal if they are carried out in contravention of s 43 or s 44 or 'of any provision of any other written law'; likewise, if strikes have any objective other than the furtherance of a trade dispute between the workers and their employer. A strike that is declared in response to an illegal lock-out is not deemed to be illegal (IRA s $45(2)$ ). 


\section{Penalties for Unlawful Strikes}

In general, penalties imposed on workers participating in illegal strikes including instigators and financial supporters are severe. They include imprisonment for up to a year. Offences relating to illegal strikes (and lockouts) are treated as 'seizable' offences for which a person may be arrested without a warrant. Bail may not be granted to an accused person or a person charged if the "Public Prosecutor certifies in writing that it is not in the public interest to grant bail to such accused person' (IRA s 50). A prosecution cannot be instituted except with the consent of the Public Prosecutor but the proviso does not affect the rule with respect to arrest, remand, or bail other than the fact that the case 'shall not be further prosecuted until that consent has been obtained' (IRA s 5 I(1)).

Punishment extends beyond mere prosecution. Any member of a trade union of workers who commences, participates, or otherwise acts in furtherance of a strike in contravention of TUA s $25 \mathrm{~A}(1)$ 'shall forthwith cease to be a member of the trade union, thereafter such member shall not be eligible to become a member of any trade union except with the prior approval of the Director General in writing' (TUA s 25A(3)). The trade union of which he is no longer a member must remove his name from its membership register, inform the Director General of Trade Unions and the member concerned of the removal, and exhibit conspicuously in its registered office a list of members whose names have been removed. In certain situations, widespread participation in an unlawful strike can wipe out the whole union.

Again, the Director General possesses almost unbridled power to order the removal of members' names from the membership register, regardless of a prosecution or conviction for an offence (TUA s 25A(5)). By virtue of section $25 \mathrm{~A}(4)$ the Director General may, 'where he is satisfied' that a contravention has occurred and the trade union concerned has failed to remove the names or where there is undue delay, order the union concerned 'to remove forthwith the names of the members concerned from its membership register' (TUA $s$ $25 \mathrm{~A}(4))$. The power is discretionary although exercisable only after he has conducted 'such investigation as he deems necessary.' It is remarkable that such power is conferred on a public servant; a power that is exercisable despite the insufficiency of evidence to bring a person to court for trial. A failure to comply with the order of the Director General is an offence.

\section{PIONEER COMPANIES}

Direct foreign investments are attracted to industries in Malaysia where they are able to secure pioneer company status under the Promotion of Investments 
Act 1986. The conferment of such status gives rise to certain privileges, including tax advantages and strict statutory control of labour.

The Employment Act 1955 contains minimum conditions of employment of workers. It is provided in the IRA s 15 that no collective agreement in relation to pioneer companies 'shall contain provisions with regard to terms and conditions of service that are more favourable to workmen than those contained in Part XII of the Employment Act 1955' with the qualification that the Minister may approve any variation. Clearly, the intention is to encourage investments in certain industries and one of the incentives is to ensure that labour costs associated with employment are sufficiently attractive for investors. Lower labour cost is achieved at the expense of workers in this instance when an artificial lid is imposed on conditions of employment, including wages for a period of 5 years which may be extendable by the Minister.

In the longer term, manipulation of labour costs is bound to affect the competitiveness of the company or industry when market forces are restored after the expiry of the 5-year honeymoon period. Of course, the honeymoon period may be indefinite given that it is elastic. The Minister may extend it 'from time to time by notification in the Gazette' and 'for such further period or periods.'

\section{CONCLUDING REMARKS}

Hallmarks of Malaysian industrial law include tight regulations of trade unions, their activities and the conduct of industrial relations. Control is secured mainly by restrictive laws and vesting wide discretionary powers in the Minister and the two Director Generals (the Director General of Trade Unions and the Director General of Industrial Relations). The absence of statutory direction for the exercise of these powers, coupled with a diminished ability of the judiciary to intervene, leads inevitably to a very timid trade union movement often unable to adequately protect the legitimate interests of its workers. The law as it currently stands is loaded in favour of employers. The current low level of industrial strife is predictable enough given the legal controls engineered by the government. It is not a reflection of a genuine partnership between employers and workers. 


\section{Notes}

1 First as Federation of Malaya comprising 11 states and later as Malaysia in 1963 to include the states of Singapore, Sabah and Sarawak. Singapore left the federation in 1965 and became a sovereign nation.

2 The Deputy Finance Minister reportedly informed Parliament that Danaharta had taken over non-performing loans worth 39.3 billion ringgit (10.3 billion US dollars) from financial institutions as of 15 October 1999.

http://www.afp.com/ext/english/nst/malaysia/991025083313.qivf30qm .$h t m l$

3 Reported on 16/10/99 in http://business-times.asial .com.sg/6/nmsia/nmsia01.html

4 For an account of capital controls, see R. Gengatharen (1999) Destablishing Financial Capital Controls: Are Capital Controls the Solution, Lawasia Journal, 12.

5 In 1978 in response to industrial action by employees of Malaysian Airline System, the Minister of Home Affairs detained several union officers under the Internal Security Act, which was a law enacted under Article 149 of the Federal Constitution. The Act provides for detention without trial. The minister said that he had detained them on the grounds, amongst others, that some employees were tampering with airplanes belonging to the airline. In any event, detention of the employees broke the back of the industrial action.

6 A limited study by Associate Professor Sheela Abraham reported in late 1999 that racial polarization at Universiti Malaya, Malaysia's oldest University, has reached a level where there is almost no interaction among the communities outside classes. While it is common knowledge that the level of social interaction among Malay, Chinese, and Indian students has decreased over the years, the paper says that racial segregation on campus is now almost complete. The survey found that 98 per cent of Malay students did not mix socially with students of other races. The figures for Chinese and Indian students were equally alarming: 99 per cent and 97 per cent, respectively. See http://straitstimes.asial.com.sg/reg/mall. Also reported in The Sun, 12 October 1999.

7 The Malayan Union was created after British reoccupation and comprised of 11 states. It was soon abandoned in the face of strong Malay opposition, to be replaced by the Federation of Malaya.

8 The government of contemporary Malaysia remains staunchly anticommunist but adopts a pragmatic approach in its dealings with 
communist or ex-communist countries in matters relating to trade and commerce.

9 That provision has been carried over to the current law and in consequence caused the federations of trade unions to remain small and weak though homogenous.

10 For an account of industrial relations law generally, see Wu Min Aun (1995) The Industrial Relations Law of Malaysia. Petaling Jaya: Longman Malaysia.

11 By the Act A717 Trade Unions (Amendment) Act 1989; Act 732 Trade Unions (Amendment) Act 1989 and Act A798 Trade Unions (Amendment) Act 1991.

12 See Part xii of the Trade Unions Act 1959 in respect of the legal requirements of trade unions. $S 75$ of the TUA makes it clear that the law relating to trade unions applies equally to a federation of trade unions. It reads:

The provisions of this Act relating to trade unions (including the provisions as to penalties) shall apply, so far as the same may be applicable, to a federation of trade unions as if such federation were a trade union.

13 See Part Xll of the Trade Unions Act 1959 in respect of legal requirements of federation of trade unions. Section 75 of the TUA makes clear that the law relating to trade unions applies equally to a federation of trade unions. It reads:

The provisions of this Act relating to trade unions (including the provisions as to penalties) shall apply, so far as the same may be applicable, to a federation of trade unions as if such federation were a trade union.

14 The power to determine similarity also applies for the purposes of $\mathrm{s} 32$ (amalgamation of trade unions). s 33 (transfer of trade unions), s 72 (formation of federation of trade unions) and $\mathrm{s} 74$ (affiliation with registered federation of trade unions).

15 'Political objects' referred to includes:

1. The payment of expenses incurred either directly or indirectly by a candidate or prospective candidate for election to either Houses of Parliament;

2. The holding of any meeting or the distribution of any literature or document in support of any such candidate or prospective candidate;

3. The maintenance of any person who is a member of either House of Parliament;

4. The registration of electors or the selection of a candidate for membership of either House of Parliament; and 
5. The holding of political meetings of any kind or the distribution of political literature or political documents of any kind.

16 See Sharifah Suhana Syed Ahmad (1992) Trade Unions in Malaysia: Organs with 'Bark or Bite?' Developments in Malaysian Law, Petaling Jaya: Pelanduk Publications 358.

17 Reported in the Star (22 May 1991) the Minister of Human Resources emphasized that trade unions should not involve themselves in politics as there would be a danger of them 'losing of sight of their original objectives,' p. 4.

18 See note no. 5.

19 See Loh Chin $v$ The Registrar of Trade Unions [1957] MLJ243 and Electrical Industry Workers Union $v$ Registrar of Trade Unions [1976] 1 MLJ177; in Minister of Human Resources Ors $v$ National Union of Hotels, Bar and Restaurant Workers, Semenanjung Malaysia and Another [1997] 3 MLJ377 the Court of Appeal held that the Director General of Trade Unions was under no duty to provide reasons for his decision; in Petaling Jaya $v$ Lee Kian Chan [1994] 1 SCR325 the Supreme Court reaffirmed the well established principle that judicial review is available in respect of jurisdictional error despite the presence of an ouster clause. For recent case law on judicial review, see Roma Chandran $v$ The Industrial Court of Malaysia \& Anor [1997] 1 MLJ145.

20 Section $25 \mathrm{~A}(7)$ provides that 'in every prosecution for an offence under this section the onus of proving that the requirements specified ... have been complied with shall be on the trade union, the member of its executive or the member of the trade union, as the case may be.'

\section{REFERENCES}

Gengatharen, R. (1999) 'Destablishing Financial Flows: Are Capital Controls the Solution?' Lawasia Journal 12.

Ilo Report (1962) Geneva 30.

Industrial Relations Act 1967.

Sharifah Suhana Syed Ahmad (1992) 'Trade Unions in Malaysia: Organs with 'Bark or Bite?' Developments in Malaysian Law. Petaling Jaya: Pelanduk Publications 358.

Toh, E. (1999) 'Will M'sia Scale New Heights Into the Future' The Business Times Singapore 30th September.

Trade Unions Act 1959.

Wu Min Aun (1995) The Industrial Relations Law of Malaysia. Petaling Jaya: Longman Malaysia. 